\title{
PALEONTOLOGICAL RESOURCES FOR GEOTOURISM IN BARMER AREA OF WESTERN RAJASTHAN, INDIA: IMPLICATION FOR A NATIONAL FOSSIL PARK DEVELOPMENT
}

\author{
Mathur SAURABH \\ Suresh Gyan Vihar University, Centre for Climate Change and Water \\ Research, Jaipur, India, e-mail: saurabh.59659@mygyanvihar.com

\section{SUDHANSHU} \\ Suresh Gyan Vihar University, Centre for Climate Change \\ and Water Research, Jaipur, India, e-mail: cm@mygyanvihar.com \\ Singh SURAJ KUMAR* \\ Suresh Gyan Vihar University, Centre for Sustainable \\ Development, Jaipur, India, e-mail: suraj.kumar@mygyanvihar.com \\ Mathur, S. C. \\ J.N.Vyas University, Department of Geology, Jodhpur, \\ India, e-mail: sureshsushmao9@gmail.com
}

\begin{abstract}
Citation: Saurabh, M., Sudhanshu, Suraj Kumar, S., \& Mathur, S.C. (2020). PALEONTOLOGICAL RESOURCES FOR GEOTOURISM IN BARMER AREA OF WESTERN RAJASTHAN, INDIA: IMPLICATION FOR A NATIONAL FOSSIL PARK DEVELOPMENT. GeoJournal of Tourism and Geosites, 28(1), 203-216. https://doi.org/10.30892/gtg.28116-463
\end{abstract}

\begin{abstract}
A unique fossil assemblage has recently been discovered from Gehun and Lunu sections of Paleocene Barmer Hill Formation in Barmer area, Western Rajasthan, India. These fossil sites have been identified on the basis of previous studies and on the present work of our research group. Aim of the present paper is to conserve the unique and rare geological materials (Asthenopodichnium fossils) as the only fossil site of such type in India. Spectacular Gehun site is easily accessible as it is located within the Barmer city. In addition, this study will also propose an idea of setting up a national fossil park at Gehun in Barmer city similar to the famous Jurassic Fossil Park of Jaisalmer in Western Rajasthan, India. Geotourism is the best tool for their promotion and conservation with additional value as branding of Paleopark for sustainable socioeconomic development of the region. Recently, field work was conducted to observe the present scenario and to identify the threats to the fossil site. Rapid urbanization, developmental activities, fossil hunting and vandalism of fossils by visitors are the main threats to these sites. Aim of the present paper is also to make further efforts to conserve paleontological sites and to recognize such sites as the significant geoheritage resources of India.
\end{abstract}

\footnotetext{
* Corresponding author
} 
Key words: Barmer Hill Formation, fossil vandalism, national Fossil Park and

Paleopark, Promotion of Geotourism, New tourist product

\section{INTRODUCTION}

Unique and rare wood boring trace fossil bearing Gehun section of Barmer Hill Formation (BHF) is located within the Barmer city and Lunu section is located about 12 $\mathrm{km}$ away from the Barmer city on Barmer-Bisala Tar Road (Figure 1). Looking to the ideal location and rich fossil assemblage, Gehun section is proposed for a national fossil park.

This fossil park will be a very valuable geotourism element of Barmer to learn about the ancient environment, ecosystem and studying the past history of Earth. Our recent field work in these unique and rare fossil sites clearly noticed that these sites are under threats to rapid urbanization, developmental activities, vandalism of fossils and illegal quarrying of sandstones locally for construction. To protect these rare fossil bearing sites and to increase awareness, no concerted efforts have been made so far.

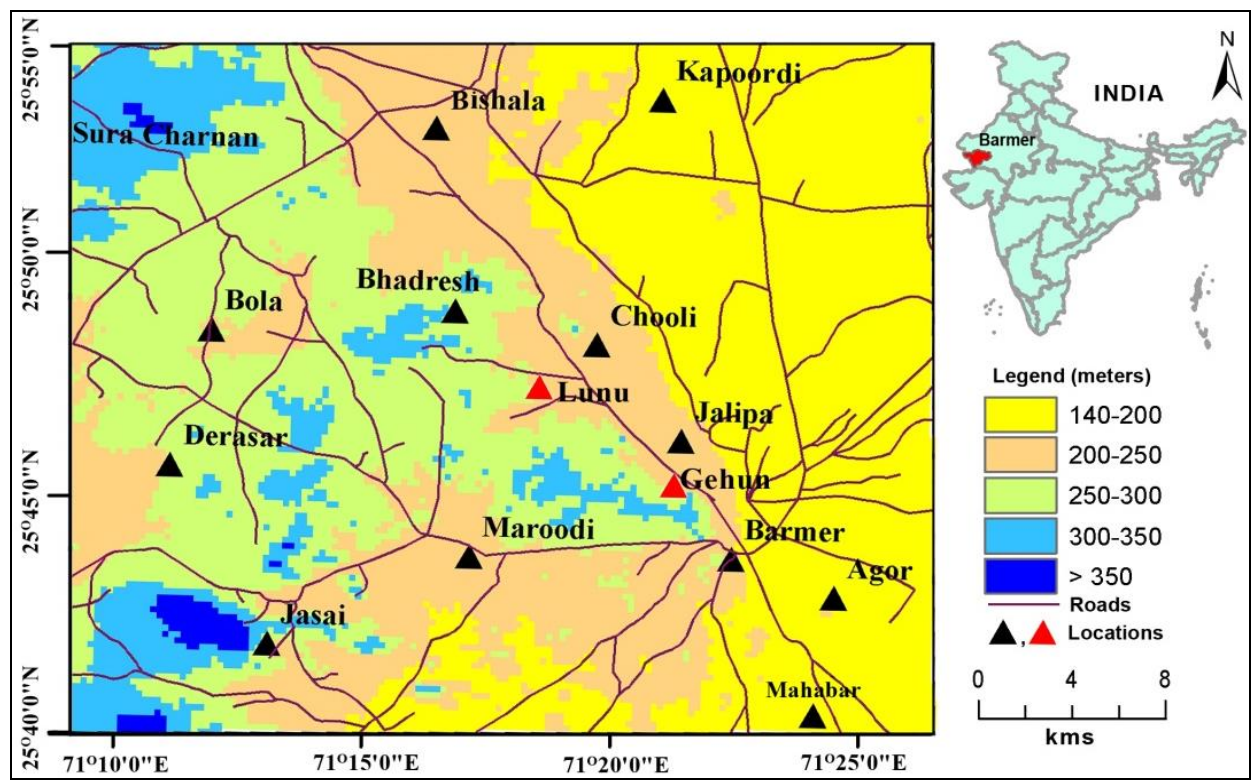

Figure 1. DEM of Barmer Area showing location of fossil-bearing Gehun and Lunu sections of Barmer Hill Formation of Barmer area, Western Rajasthan, India

Conservation of these sites can be achieved by involving the local communities and local administration of Barmer. In this context, objective of present paper is to discuss a brief overview of geology of Gehun section, brief explanation and significance of fossils, identification of major threats to the fossil site and initiate the idea for proposing the ever first fossil park with branding of potential Paleopark in Barmer.

\section{LITERATURE REVIEW}

Barmer area is endowed with huge and bold ridges of rocks of Malani Igneous Suite (MIS) and associated alkaline suite of Sarnu Dandali Igneous complex of Cretaceous age 
(Srivastava, 1988; Basu et al., 1993). Only a small ridge named here as Gehun section represent sedimentary rocks in this igneous territory of the Barmer city (Mathur et al., 2016). Dasgupta, (1973) first named these sediments as Barmer Hill Formation (BHF).

Recently, India's only and rare wood boring trace fossils, Asthenopodichnium (May fly and Rotten algae fossils) have been reported (Mathur et al., 2018) along with petrified wood and Teredolites (Mathur et al., 2016); Gyroliths, Thalassinoids and Ophiomorpha trace fossils (Shekhawat, 2016) from Gehun section. Earlier, Angiosperm floral assemblage (Matoniaceous fern, acutifolium, phlebopteris, ptillophylumandcycades, ferns) have been reported by Dasgupta, (1974) from Lunusection of Paleocene BHF.

To identify and describe the various fossils from BHF, work of Uchman et al., 1995, 2007; Moran et al., 2010; Campbell \& Baxter, 1979; Kelly \& Bromley, 1984; Hantzschel, 1975 have been utilized. It is important to note here that the Asthenopodichnium trace fossils have been recorded earlier only from Lithuania, USA, Egypt, Czech Republic, Argentina, New Mexico (Uchman et al., 2007; Moran et al., 2010) and India's first site indicating international significance of Gehun site of Barmer, India.

\section{METHODOLOGICAL FRAMEWORK}

The objective of development of Barmer national Fossil Park with IPA paleopark tag for socioeconomic development of the region can be achieved through the methodology given below (Figure 1, a). Based on previous works and field, Petrographic, paleontological and remote sensing data, georesources of national and global significance were identified in the study area (GGN, 2006). Further, important geosites of significant fossils were identified based on Yang et al., (2011). With proper protection and conservation plan for identified geosites, a national fossil park is proposed which can further get IPA paleopark tag as per Lipps, (2009).

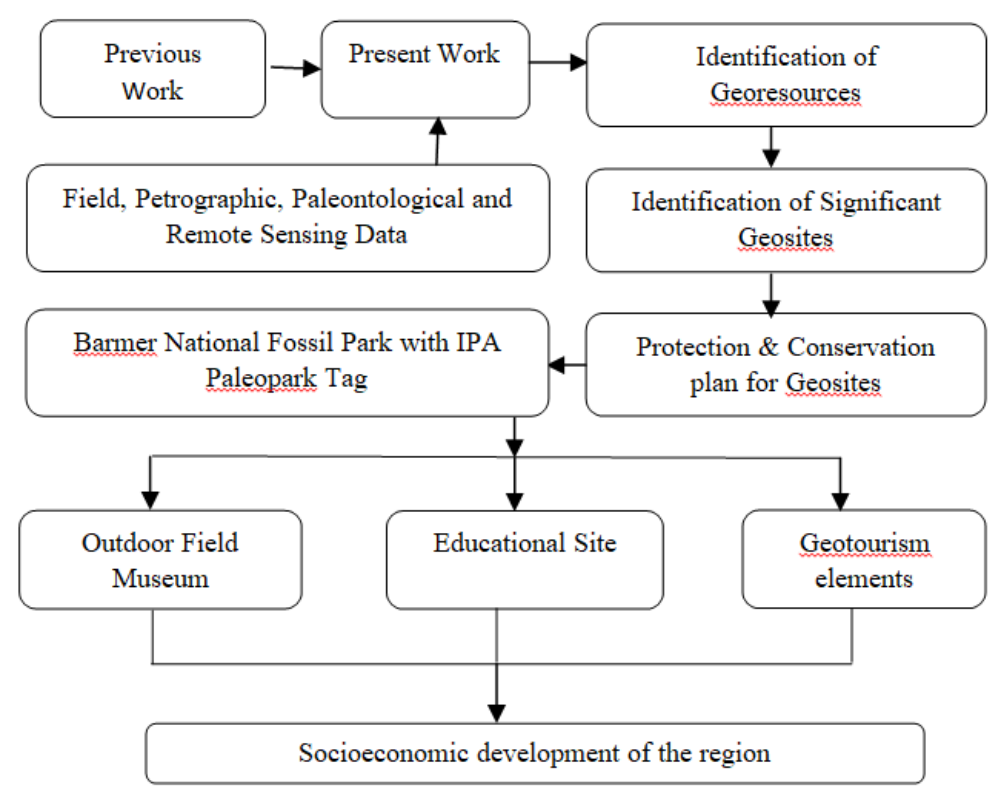

Figure 1, a. Proposed methodology for Barmer National Fossil Park

Additionally, with ideal location, these geosites can serve as an important outdoor field museum showcasing geodiversity among rocks and fossils. Combination of all 
these geosites in one complex type geosite will be a centre of education for students and geotourism to enjoy and admire by general public. All these aspects of tourism will contribute to socio-economic development of the region.

\section{GEOLOGICAL ATTRIBUTES OF BARMER AREA:}

Excellent to scattered outcrops of fossil bearing Paleocene rocks of BHF are mainly exposed about $5 \mathrm{~km}$ in north western direction from Barmer railway station in the Barmer city up to Lunu in north for a strike length of about fifteen km (Figure 1).

BHF unconformably overlay the basement of Rhyolite of Malani Igneous Suite (Dasgupta, 1974; Roy \& Jakhar, 2002; Mathur et al., (2016). However Shrivastava, (1988), Basu, (1993) and Shekhawat, (2016) suggested that the rhyolite of MIS extensively exposed in the eastern direction to Barmer city and alkaline complex around Sarnu area in western direction are of Cretaceous age. Late Cretaceous Fatehgarh Formation is underlain by BHF in north western side while BHF is underlain by the Akli Member of Dharvi Dungar Formation in north direction to Barmer (Figure 2; Mathur \& Kumar, 2003; Mathur et al., 2006; Paul et al., 2016).

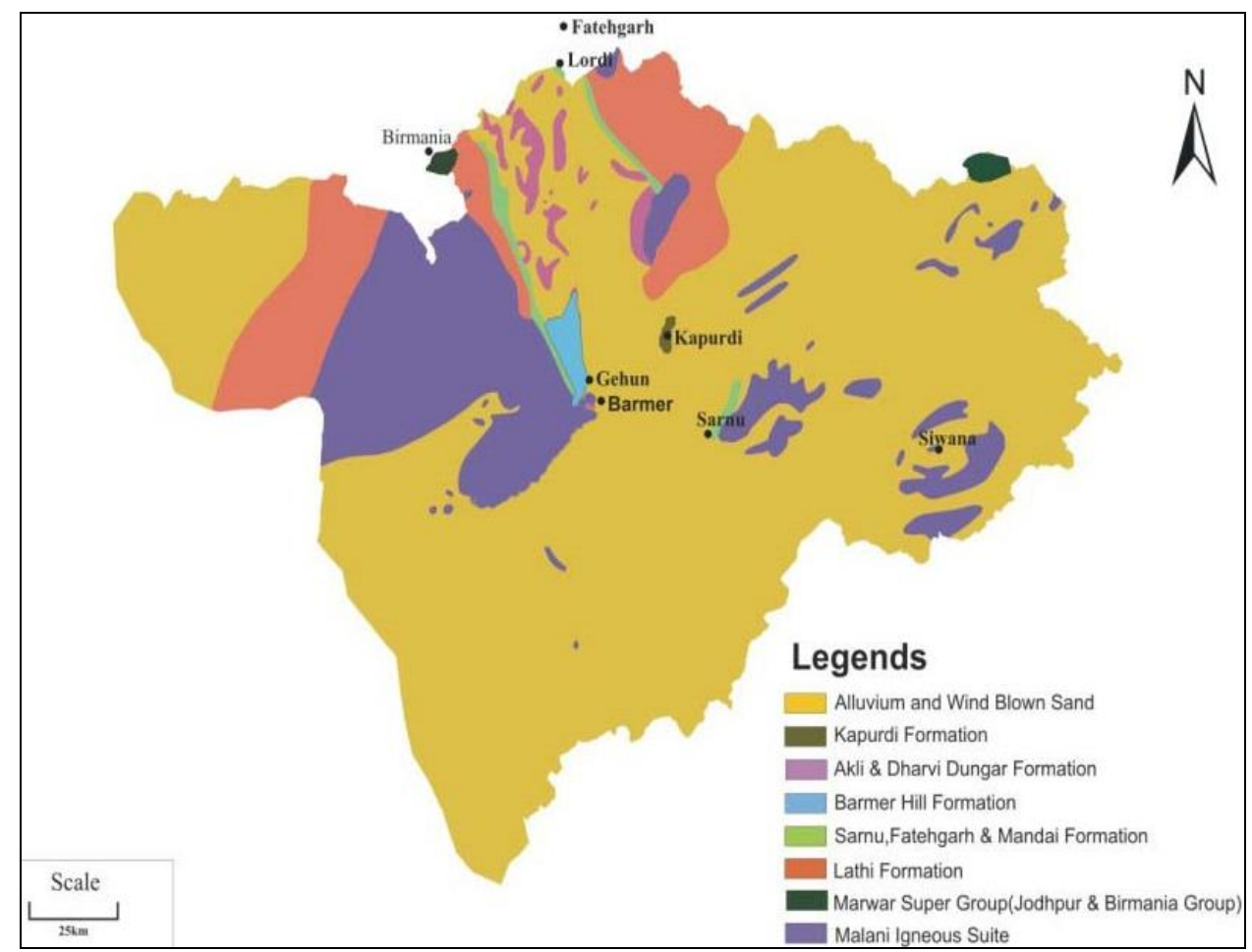

Figure 2. Geological Map of Barmer district showing outcrops of various formations with BHF

With this stratigraphic disposition at Gehun section, BHF forms a beautiful landscape with bold ridges and isolated hills (Plate-1a) pediments and pediment like surfaces covering an area of about two sq. km. Fifty-meter thick BHF at Gehun is divided into Lower and Upper Members on surface outcrops. Lower Member comprise of four fining upward cycles of siliciclastic sequences (Mathur et al., 2018). Each cycle commences with conglomerate at the base. It is followed by pebbly sandstone; coarse, 
medium and fine- grained sandstone with interbedded siltstone at the top (Figure 3 and Plate-1b). Fine grained sandstone of each cycle preserves wood logs of Asthenopodichnium wood boring trace fossils and petrified wood (Plate-1c, 1d, e, f, 2a and 2b). These cyclic sequences represent channel lag deposits to braided riverine depositional setting of the lower member of BHF with local sediment source from Malani rhyolite. Upper member of BHF is composed of carbonate dominated lithofacies (Plate-2c) which comprise of rich assemblage of Teredolites, bivalve shells (Plate-2d, e and f); Gyroliths(Plate-3a); Ophiomorpha and Thalassinoid trace fossils (Plate-3b, c and d) indicate shallow swampy near coastal to subtidal marine environment (Mathur et al., 2016; Shekhawat,2016).

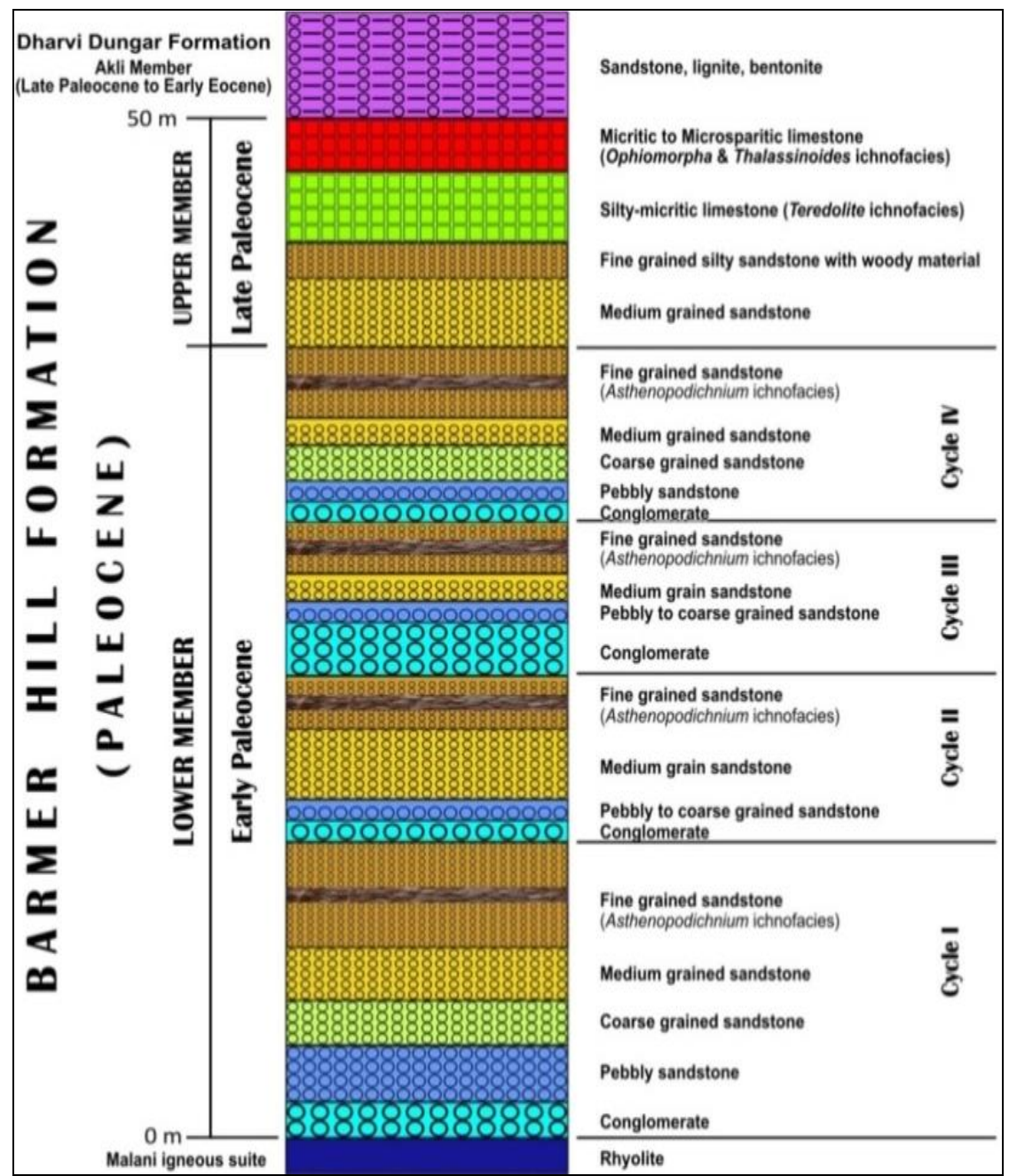

Figure 3. Lithostratigraphic section of Barmer Hill Formation at Gehun section (after Mathur et al., 2018)

\section{FOSSIL RECORD OF GEHUN AREA: AN OVERVIEW}

Varieties of trace fossils are discussed below from Gehun Section of BHF along with petrified wood based on the work of Mathur et al., 2016; Shekhawat, 2016; Mathur et al., 2018 and identification of many other ideal localities of fossils during our recent field work: 


\subsection{Asthenopodichnium}

Excellently preserved, smaller to larger Asthenopodichnium trace fossils are found in full relief in wood logs in fine grained sand stones of Gehun section of BHF (Plate-1c and 1d). These fossils are identified as Asthenopodichnium lignorum (Plate-1e) and Asthenopodichnium lithuanicum (Plate-1f) which are abundantly and uniformly distributed in ideal and bookish forms parallel to the bedding planes. This distribution of Asthenopodichnium is similar to imbrications structure and their longer pointed part indicates south-south westward paleocurrent direction (Plate-1d). Asthenopodichnium lignorum trace fossils are loosely to tightly packed, pouch-like burrows having lozenge or almond-shaped structures (Plate-1e) while Asthenopodichnium lithuanicum are characteristically J-shaped structures (Plate-1f). Wood logs range in size from few inches to a meter size with $10 \mathrm{~cm}$ to about $30 \mathrm{~cm}$ thick forming layers in the fine-grained sandstone (Plate-1d). A. lignorum trace fossils are considered as feeding and dwelling burrows produced by wood-rotten fungi whereas A. lithuanicum are supposed to be feeding and dwelling burrows produced by Mayfly nymphs and larvae (Mathur et al., 2016; Mathur et al., 2018). At Gehun section rare preservation of Asthenopodichnium fossils were possible due to development of iron hydroxide (Goethite) rinds and casts around them. The goethite rinds and casts were probably formed by microbial decay of wood logs submerged in channels or bars of the river, when wood logs and other woody material died. Subsequently, the vascular cambium and secondary phloem undergo decay processes. At the same time when mineral or ion-laden water came in contact with died material and could react to precipitate goethite rinds around the borings which are expressed as positive relief in the horizon. Significantly, it is seventh reporting from the World in Barmer and first reporting from India indicating its international significance and rarity of preservation.

\subsection{Petrified Wood}

Well preserved, few centimeters to few meter sized wood logs (Plate-1c) and petrified wood (Plate-2a) occur in fine grained sandstones of all cycles in BHF. Petrified wood at Gehun section is probably formed by tree and plants which completely transformed to rock by the process of permineralization. Under this process, organic material has been replaced with silicate minerals, mainly quartz and Jasper which retained the original structure of the stem tissues. Not being impressions or compressions, petrified wood is simply a three-dimensional representation of original organic material. The petrification process commences when wood is buried under fluvial sediments which are initially passes through the environment with lack of oxygen. Subsequently, mineral-laden water start flowing through the covering material in plantcells; as the plant's lignin and cellulose decay, a stonemould of silica forms in its place to form petrified wood ( $c . f$. Campbell \& Baxter, 1979). It has been found that petrified wood occurring in fine grained sandstone in the lower cycle are partially coalified, silicified and jasperified. This imparts them a beautiful and attractive colors (Plate 2b). Wood logs with Asthenopodichnium and petrified wood indicate the process of terrestrial fluvial environment. This represents that presently Barmer area which has arid-semi arid climatic conditions presently, was a luxuriant forest during the Paleocene time and a big riverine system was operated here.

\subsection{Teredolites}

Beautiful preservation of Teredolitesin the Upper Member of Gehun section occur as clusters of stubby to club-like flask-shaped tubes in wood ground sinmicritic limestone (Plate 2d and 2e). Teredolites are developedin a pattern which is vertical or oblique to the bedding. These are boring bivalves belonging to the family Teridinidae (Kelly and Bromley, 1984). In micritic limestone of BHF, the pieces and fragmentary bivalve shells are abundantly dispersed, showing high energy environment (Plate 2f). Teredolites are 
considered as dwelling and feeding traces produced by wood-boring bivalves (Teredinids) also called Ship-worms (Kelly \& Bromley, 1984). Teredolites are indicators of brackish to marine environment and normally linked to the base level rise in marginal marine environment. Hence, Teredolites occurrences indicate extended estuarine to transgression conditions. The reporting of Teredolites has been made from India from many paleontological sites. These include: Ukra Hill Formation, Bhuj Formation, Kaladungar Formation and Vastan lignite mine of Gujarat in Kachchh Basin (Desai \& Saklani, 2012; Kumar et al., 2011); Bhuban Formation, Aizwal district, Mizoram (Mehrotra et al; 2001) Garudamangalam Formation, Tamil Nadu of Cauvery Basin (Tiwari et al., 2007). Seventh reporting is from BHF at Gehun in Barmer (Mathur et al., 2016) showing their importance and rarity in India.

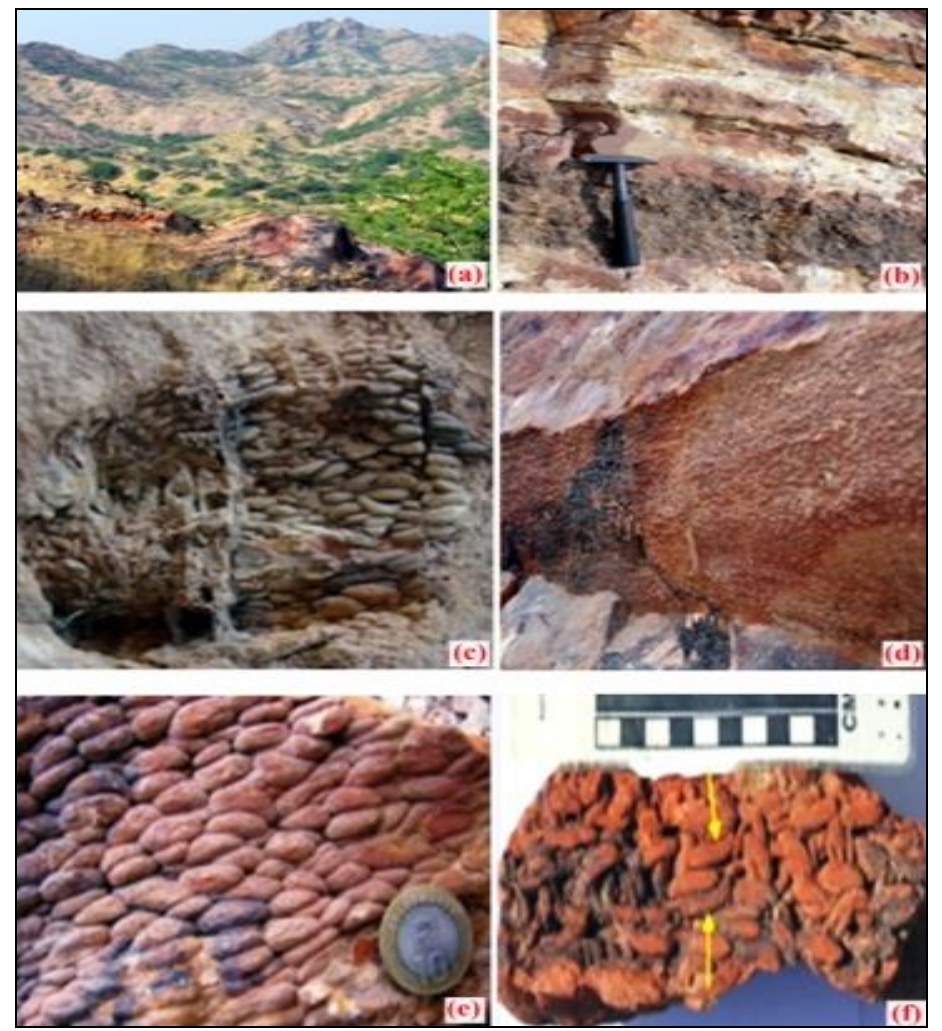

Plate 1 a. Spectacular landscape of rocks of Barmer Hill Formation (Foreground) and rocks of Malani Igneous Suite; b. Outcrop of fining upward sequence showing conglomerate at base to fine grained sand stone at the top; c. A wood log with large Asthenopodichnium preserved in fine grained sandstone; d. A large wood log in fine sandstone showing imbrications of tightly packed pouches of Asthenopodichniu; e. Tightly packed lozege and almond shaped Asthenopodichnium lignorum trace fossils; f. Tightly packed J- shaped Asthenopodichnium lithuanicum trace fossils

\subsection{Gyroliths}

Well preserved left or right-handed coiled and spiral shaped Gyroliths burrowtrace fossils are found in microsparitic limestoneof Upper Member of Gehun section (Plate 3a). No surface ornamentation appears in the whorls of Gyroliths. Entire burrow structures are ranging in size from $30 \mathrm{~cm}$ to $50 \mathrm{~cm}$ while diameter of the burrow tubes vary from 2$3.5 \mathrm{~cm}$. Gyroliths are feeding and dwelling burrows probably made by decapods, 
Crustaceans (Hantzchel, 1975). Gyrolithsexhibit restricted marginal marine environment (Bromley \& Frey, 1974; Fillion \& Pickerill, 1990). Teredolites and Gyrolithsclearly indicate that large fluvial system of Barmer grades into marine environment through development of estuarine environment indicating unique ancient ecosystem of the region.
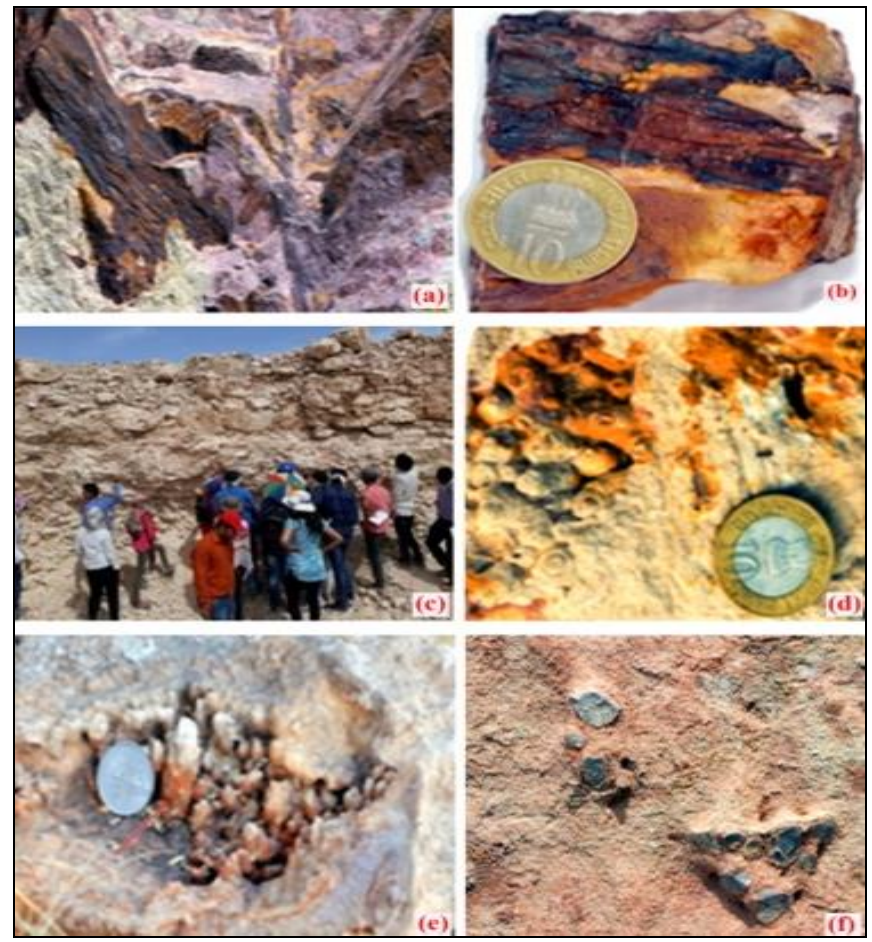

Plate 2 a. Large log of non-coalified petrified wood preserved in fine grained sandstone;

b. Hand specimen of petrified wood showing partially coalified at top and jasperified at the base;

c. Students observing carbonate dominated Upper Member of Gehun section and its fossils;

d \& e. Bulb, club and flask shaped tubes of Teredolites preserved in micritic limestone;

f. Pieces and fragments of Teridinae shells preserved in micritic limestone

\subsection{Thalassinoids and Ophiomorpha}

Thalassinoid and Ophiomorpha trace fossils occur in same horizon of fine grained microsparitic limestone of Upper Member on top of Gehun section of BHF. Fragmented and discontinuous tubes of Thalassinoids are embedded in calcite to clayey matrix in which beddings are not so clear. These trace fossils show both branched and unbranched tubes (Plate3b). Thalassinoid burrow system at Gehun is deposited horizontal to oblique and sometime vertical to the bedding plane. Theyaresaid to be a feeding burrow system created under oxygenated water inner coastal shallow marine environment (Ekdale, 1992). Preservation of Ophiomorpha commonly occurs as vertical or horizontal and cylindrical tunnel system in fine grained microsparitic limestone of Upper Member of BHF. Sometimes, it is branched and covered by elongated or irregular pellets arranged perpendicular to their longer axis. Some horizontal segments of Ophiomorpha may lack knobby appearance due to differential weathering and erosion which often results into empty tubes as seen on surface and in transverse section (Plate-3c and $3 \mathrm{~d}$ ). Ophiomorpha is considered as feeding and dwelling burrow of crustaceans which normally represents sub-tidal environment (Uchman, 1995; 2007). 
Paleontological Resources for Geotourism in Barmer Area of Western Rajasthan, India: Implication for a National Fossil Park Development

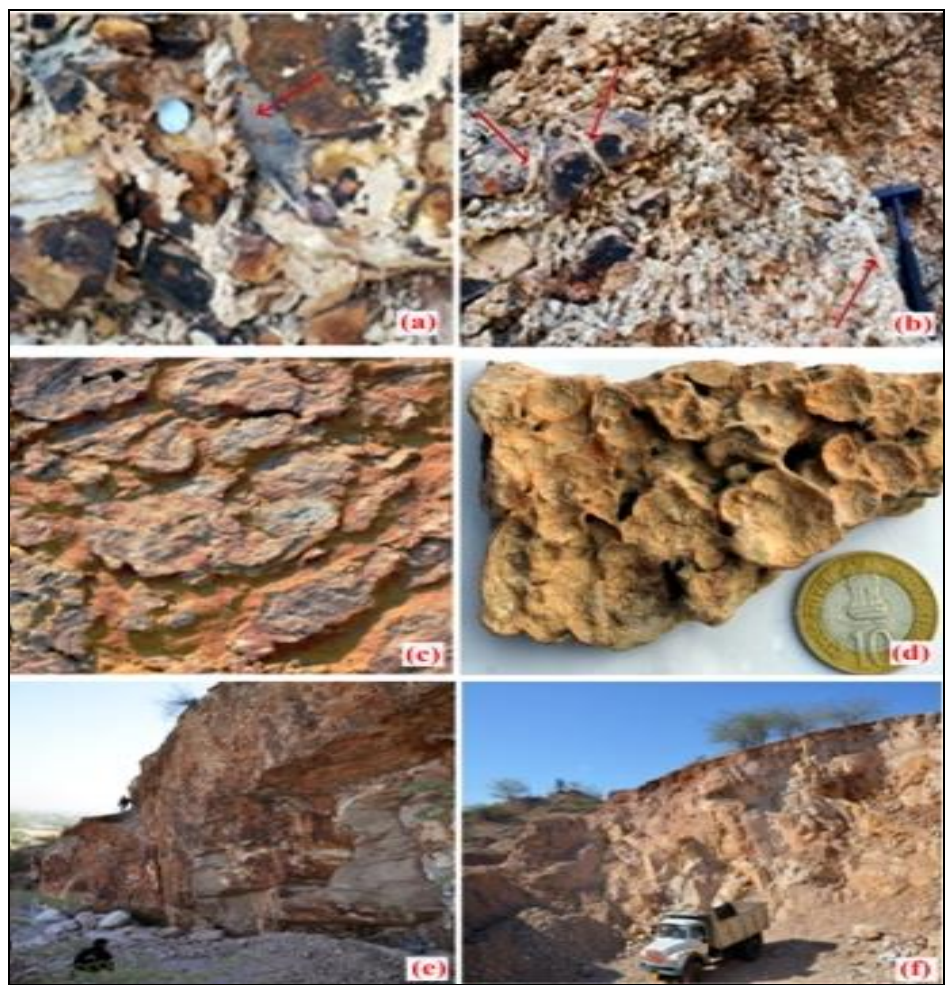

Plate 3 a. Gyroliths showing spiral burrow having uniform diameter of burrow tube present in microsparitic limestone; $\mathrm{b}$. Unbranched fragmented tubes of Thalassinoidtrace fossils preserved in microsparitic limestone; c. Empty Ophiomorpha tubes having lack of knobby appearance due to differential weathering as seen on outcrop; d. Hand specimen of Ophiomorpha showing depressional tubes without knob; e. Anthropological threat to Asthenopodichnium bearing Lower Member of Gehun section being destructed for clearing site to construct houses; $f$. Threat to fossil site at Gehun section due to illegal mining

\section{THREATS TO FOSSIL SITES IN BARMER AREA}

Fossil sites of Gehun of Barmer are undoubtedly containing unique and rare fossils which are significant georesources of India. Rare fossil sites of Barmer are under great threats and should be protected for future generation to be handled as proposed below:

\subsection{Awareness and Education}

Barmer is the place of vast geological education as it is endowed with landscape of globally one of the largest acidic, orogenic and terrestrial volcanic province (Malani Igneous Suite), alkaline suites and its mineralization of REE of Cretaceous age, huge lignite and coal bed Methane occurrences along with one of the largest petroleum and Bentonite deposits of India (Bhushan, 1975; 2000; Maheshwari et al., 1996; Mathur et al., 2009; Compton, 2009, Dolson et al., 2015). Additionally, global phosphogenic and mass extinction events (rich assemblage of fossils of fishes, crocodile, dinosaur, turtle, trace fossils and gastropods) and significant framework elements (magnetic spherule, dust, ejecta material related to KTB of volcanic and impact events in Fatehgarh Formation (Mathur et al., 2005a \& b; 2006; 2019a \& b) are other specialties along with present fossiliferous site (Gehun) of Barmer area. Being a geologically significant area, many geologists are interested to visit Barmer for study and research purposes. However, 
general public and tourists are not aware of geological uniqueness of the region. In order to spread awareness; sign boards, brochures, field guide, tourist guides, articles in newspapers and social media should be prepared and made available by geological fraternity at local and national level to serve the purpose of education and geotourism.

\subsection{Rapid Urbanization and Developmental Activities}

After 2004 with the petroleum discovery by CAIRN, India in Barmer Basin (Compton, 2009; Dolson et al., 2015), Barmer city has undergone rapid urbanization and development. Secondly, the fossil sites at Gehun are easily accessible and are located in a growing residential colony in the Barmer city. Therefore, this site is severely on the verge of complete exhaustion as outcrops will be lost and one day houses may be constructed utilizing this land and geologically significant rare material for construction. Hence, these outcrops which are excellently exposed should be cared by geologists, local people and administration to safeguard them from urbanization and developmental activities.

\subsection{Excavation of fossils bearing rocks and fossil vandalism}

Fossil sites of Barmer are partially located on government/public lands and are not under reserve or protected category. For instance, the local people are not aware of the importance of these rocks and rare fossils, so the land is freely available for illegal mining and to excavate fossil bearing rocks to be used for construction purposes by local people (Plate-3d and-3e). Vandalism of fossils by fossil hunters and antique thieves are another threats to the sites as beautiful and rare fossils are collected and are brought for exhibition in museums of institutes by geologists themselves. This practice actually disturbs the insitu values of fossils. Collection and vandalism of rare fossils without permission and selling them for price is an unethical act. In absence of rules and regulation against vandalism of fossils in India, important fossil sites including Barmer are endangered for illegal excavation and collection of fossils.

\section{OVERVIEW OF CONSERVATION OF FOSSILS AND FOSSIL SITES:}

J.N.V. University, Jodhpur and S.G.V. University, Jaipur are proposing some initiatives to protect and conserve fossils and fossil sites of India including Gehun fossil site in the Barmer area through their joint research collaboration. Additionally, these initiatives also aim to allow scientific study leading to public educational and recreational activities for benefits to empower local community for their economic growth through geotourism from these sites. For this, we should be aware about the importance of paleontological material as the first step and should discourage to display them in museums because, it is considered as unethical act at international level. Rather, one must be encouraged to conserve them insitu at their original position in the fossil sites by developing a fossil park mainly for scientific and geotourism purposes. In this context, Lipps (2009), conceptualized that local fossil sites having national as well as international significance should be protected insitu as a paleontological treasure. It has to be made essential through some government rules, acts and legislation because these sites provide an understanding of history of life on Earth to the present and future scientific researchers. Unfortunately, India does not have any rule and regulation till date against fossil vandalism and conservations. In this context, recently on $6^{\text {th }}$ Aug. 2019, Society of Earth Scientists, Lucknow and Indian National Science Academy, New Delhi have proposed a Geodiversity Act-2019 which is planned to be submitted to the government of India. One of the co-authors (S.C. Mathur) was a member of the committee of the first Geoheritage Act of India. Secondly, these significant georesources can be managed by protecting them efficiently by developing fossil parks as done in New Zealand (Heyward, 2009), Malaysia (Dony et al., 2014), Thailand (KritwonIn \& Singtuen, 2018) and in other countries. Many countries have promoted, protected 
and conserved their significant paleontological sites in a variety of ways to recognize their paleontological heritage by passing legislation against fossil collection and vandalism.

As a result, under UNESCO's World Heritage Program, 878 sites with cultural and natural heritage values along with 147 Geoparks in 41 countries have been recognized and developed in these countries (globalgeoparks.org and GGN, 2006). Surprisingly, despite of rich geoheritage, India does not have a single geopark. Many of these recognized sites are paleontological and fossil conservation sites. Additionally, International Paleontological Association (IPA) established Paleopark in order to protect endangered fossil sites by establishing fossil parks that conserve fossil sites in ground for a primary source of scientific data, educational opportunities, recreational and geo-touristic activities.

There is no Indian paleontological site or fossil park included under IPA catalog despite of the fact that many of Indian significant fossil sites are endangered and are on the verge of extinction. However, Geological Survey of India (GSI) had declared ten paleontological sites as National Geological Monuments (NGM; GSI 2001a\&b), out of which Rajasthan has three NGM and Western Rajasthan has only one (Akal fossil park, Jaisalmer with petrified wood of Jurassic age). Despite of this declaration, no concerted efforts have been done for their detailed study, management and significance. Though, these sites are protected areas, however, lack of proper safety and vandalism practices resulted into the loss of fossils from many significant sites. Unfortunately, at Akal Fossil Park, petrified wood samples has been lost with the time and only few specimens are left in the cage for the observation by visitors. This is one of the great losses of significant georesources of a Jurassic park in India. In light of the above facts, recently discovered rare fossil sites of Gehun in Barmer area can be a significant potential candidate for establishing a national fossil park with Paleopark branding in western Rajasthan, India.

\section{PROPOSED BARMER FOSSIL PARK AND FIELD MUSEUM}

The proposed Barmer fossil park will be a significant place where rare fossils and host rocks will be protected and conserved at their insitu exposures. Secondly, the park would be an excellent outdoor field museum with different aspects to traditional indoor museum where collection of fossils could be made through the practice of vandalism. Thirdly, this fossil park will be an attractive site with original landscape; its various features and fossils which will provide a broad spectrum and exhibitof the rare fossils in their original place. Ultimately, the site will play an important role not only in conserving the fossils but also would be available insitu for education to public, research for geoscientists in order to establish the value of fossils to understand the history of lifeand other geological aspects of Paleocene period of the region. Additionally, these sites arerepresenting a landform of luxuriant forest with large fluvial to marine system of Paleocenetime in this part of India which is presently an arid zone. Internationally, there are several examples of successful establishment of fossil park and Paleontological field museums by protecting and conservation of fossil sites (GGN, 2006; Santucci, 2017).

One can easily understand this unique concept by following excellent examples: Petrified wood park and Dinosaur ridge in USA (Santucci, 2017), Wadi Al-Hatim fossil park (Whale Valley) in Sahara Desert, Egypt (UNEP-WCMC, 2011), Paleontological National fossil parks in China (Yang et al., 2011), PhuKumKhao Dinosaur Paleontological Site, Thailand (Boonchai et al., 2009) and Paleontological Site of Airing, Malaysia (Nazaruddinand Othman, 2014). All thesefossil parks displayed and conserved their unique and rare fossils by establishing fossil park, paleopark and Geopark. Similar efforts should be made for protection and conservation of paleontological sites including Barmer fossil sites in India. For instance, the proposed Barmer fossil park is expected to provide a unique and 
interesting view of spectacular landscape and life history of 65 to 55 million years old Paleocene period. The site will attract a wide attention of paleontologists, geologists and researchers for scientific studies pertaining to taxonomy, taphonomy, paleoecology, paleoclimatology, paleobiogeography of fossils and depositional environment of sedimentary rocks. Common people and visitors will learn and enjoy the uniqueness of exceptionally beautiful fossils and their preservation process in rocks. Educational tours for students and guided tours for tourists will be an additional benefit of Barmerfossil park along with opportunities for camping, lecture and hiking activities etc.

Looking to the enormous benefits, Barmer fossil sites urgently required protection and conservation through a national fossil park. This can be done by involving all related agencies (academic institutions, research centers, state and central govt. organizations) and individuals (paleontologists, geologists/geoscientists, academicians). For this task, local administration, local tourism organization and tourist industries (travel agent, carriers etc.) who are responsible for tourism development. Based on the present knowledge and through this paper, proposed Fossil Park must have an adequate and acceptable space (boundary) which should be managed by government may be on PPD mode. Each fossil and unique host rock sites proposed willbe described briefly, as sign boards, pamphlets, brochures, small booklets in tangible language (in English and local language) to provide knowledge to a range of visitors i.e. students, tourists, educationists, scientists etc. Since, proposed Barmer Fossil Park is situated within the Barmer city so some facilities (visitor center, café and restaurant etc.) and infrastructure (road and park) should also be designed and built for the comfort of visitors wherein the owner may charge money (ticket) from visitors. After creating such facilities with complete geological information, the site canqualify for a Paleopark for which a Dozier to be prepared and submitted to IPA in coming future.

\section{DISCUSSIONS}

Proposed Barmer Fossil Park represents only the site containing unique and rare preservation of Paleocene wood boring Asthenopodichnium trace fossils in India. In addition, it is only seventh such site of the world (Mathur et al., 2018). This discovery of fossils by our group inspired us to protect and conserve themurgently, as it is severely threatened by anthropological and vandalism activities going on there. This site also comprises spectacular outcrops of Paleocene sedimentary rocks and spectacular landscape of rocks of MIS of global significance. Additionally, this small outcrop (two sq. km. area) represents classical fluvial to marine sedimentary sequences and a unique ecosystem and paleolife of these environments. It is collectively a rich representative site and can be proved as important paleontological georesources of Barmer. Despite of being a significant paleontological resource, it is endangered due to the threats of anthropology (development and rapid growth of urbanization) and vandalism activities. Geoscientists and local administration should think creatively to achieve proper protection of this site in form of proposed Barmer Fossil Park by conserving its rocks and unique fossils.

The establishment of field museum in form of Barmer Fossil Park will increase awareness regarding importance of fossils among people, increase government and public interest and also expand geotourism for socioeconomic benefit of the area. This paper is certainly promoting the data of these unique fossils in geoscientific and geotourism aspects to make people understand the geological processes and care for fossils through the conservation of geoheritage and paleolifewhich was significantly developed just after the K/T boundary extinction in this part of India (Mathuretal, 2006; 2019).

Secondly, BHF clearly indicate non-coalification of wood material having rich assemblage of wood boring trace fossils while overlying Akal Member of Dharvi Dungar 
Paleontological Resources for Geotourism in Barmer Area of Western Rajasthan, India: Implication for a National Fossil Park Development

Formation witnessed by the presence of huge deposits of lignite (Coalified wood) inthe nearby landscapes indicating geodiversity among rocks of the Barmer. These aspects of BHF provide additional international significance to proposed Barmer Fossil Park.

\section{CONCLUSION}

Geological features including preservation of fossils which took millions of years to form should be conserved insitu. Fossils contain a range of values that require special care and protection. Gehun section of Barmer is an excellent example of preservation of unique and rare fossils. Unfortunately, fossil bearing outcrops of Gehun section of Barmer have been damaged due to large activities of construction and development works with illegal quarrying. Site is also endangered due to fossil hunting, vandalism and antique theft practices. To protect this fossil site in form of National Fossil Park will not only help in conserving the fossil sites of scientific and educational values but also will promote geotourism in the historical and cultural Barmer city. For this purpose, suitable infrastructure should be developed with respect to protection of natural heritage by involving local communities, geoscientists and government authorities.

\section{Aknowlegments}

Authors are thankful to Dr. N.S. Shekhawat for providing and permitting to reuse certain photographs and material used in his research.We sincerely thanks Dr. V.S. Parihar and Dr. S.L. Nama for field work and identification of fossils.We sincerely acknowledge the help and assistance rendered by colleagues and students ofDepartment of Geology, JNVU: Dr. S.R. Jakhar, Dr. Shiv Singh, Dr. C.P. Khichi, Mr. Hukma Ram, Mr. Ashish, Mr. Ganpat, Mr. Bhura Ram and Mr. JitendraParihar. Authors are thankful to reviewers for their thoughtful suggestions and comments.

\section{REFERENCES}

Basu, A.R., Renne, P.R., Dasgupta, D. K., Teichmann \& Poreda, R.J. (1993). Early and late alkali igneous pulses and high 3 He plume origin for the Deccan Flood Basalt. Science, 261,902-906.

Bhushan, S.K. (1975).The Malani rhyolite. Jour. Ind. Min. Geological Survey of India, 30 (2),99-100.

Bhushan, S.K. (2000).Malani rhyolite - A review.Gondwana Research, 3 (1),65-77.

Boonchai, N., Grote P.J. \& Jintasakul,P.(2009). Paleontological parks and museums and prominent fossil sites in Thailand and their importance in the conservation of fossils. InLipps J.H. \& Granier B.R.C. (eds.) (2009). Paleopark - The protection and conservation of fossil sites worldwide. - Carnets de Géologie / Notebooks on Geology, Brest, Book, 75-95.

Campbell, J.A. \& Baxter M.S. (1979). Radiocarbon measurements on submerged forest floating chronologies. Publishing Group, 278 (5703), 409-413.

Compton, P.M. (2009). The geology of the Barmer Basin, Rajasthan, India, and the origin of its major oil reservoir, The Fatehgarh Formation. Petroleum Geosciences, 15, 117-190.

Dasgupta, S.K. (1974). A revision on the Mesozoic-Tertiary stratigraphy of the Jaisalmer. Jour of Earth Science, 2(1), 77-94.

Desai, B.G. \& Saklani, R.D. (2012). Significance of the trace fossil BalanoglossitesMägdefrau, 1932 from the Lower Cretaceous Guneri member (Bhuj Formation) of the Guneri dome, Kachchh, India. Swiss. JournalPaleontology, 131(1), 255-263.

Dony, A., Nazaruddin, A. \& Othman, R. (2014). Geoheritage Conservation of PaleontologicalSites in Aring Area, GuaMusang District, Kelantan, Malaysia.International. Journalof Advanced Science Engineering Information Technology, 4 (1), 14-19.

Ekdale, A. (1992). Muckraling and mudslinging: the joy of deposits feedings. In: C.G. Maples and R.R. West (Eds.), Trace Fossils. The Paleontological Society short course in Paleontology, 5, 145-171.

Fillion, D. \& Pickerill, R.K. (1990). Ichnology of the upper Cambrian- lower Ordovician Bell Island and Wabana Groups of eastern Newfoundland. Palaeontogeographica Canadiana, 7, 119-126.

Hantzchel, W. (1975). Trace fossils and problematica. In: Moor. R.C.(eds.), Treatise on Invertebrate Paleontology, Part W, Supplement 1. Geol. Soc. America Univ. Kansas press, 269.

Hayward, B.W. (2009). Protecting fossil sites in New Zealand. Notebooks on Geology, 49-64.

Kelly S.R.A. \& Bromley R.G. (1984). Iconological nomenclature of clavate borings. Journal of Paleontology, $27,793-807$. 
KritWon-In \& Singtuen, V. (2018). Geoheritage Conservation for Sustainable Geotourism in Petrified Wood Forest Park, TAK Province, Thailand.The Turkish Online Journal of Design, Art and Communication, special volume,1532-1537.

Kumar, K., Singh, H. \& Rana, R.S. (2011). IchnospeciesTeredoliteslongissimus and Teredinid Body Fossils from the Early Eocene of India-Taphonomic and PalaeoenvironmentalImplications.Ichnos,18(2),57-71.

Lipps, J. H. (2009). PaleoParks: Our paleontological heritageprotected and conserved in the field worldwide. Notebooks on Geology Book 2009/03, [http://paleopolis.rediris.es/cg/CG2009_BOOK_03/CG2009_ BOOK_o3_Chaptero1.pdf].

Maheshwari, A., Coltori, M., Sial, A.N. \& Mariano, G. (1996). Crustal influences in the Petrogenesis of the Malani rhyolites, south- western Rajasthan, combined trace elements and isotope constraints. J. Geol. Soc. India, 7, 611-619.

Mathur, S.C. \& Mathur. S.K. (2003). Sedimentation in Barmer Basin. Journal Geological Society of India, 61 (3), 368-369.

Mathur, S.C., Gaur, S.D., Loyal, R.S., Tripathi A., Tripathi, R.P. \& Gupta, A. (2005a). First report on magnetic spherules recovered from Maastrichtian bone bed in the sedimentary sequence of Fatehgarh Formation, Barmer Basin, India. Current Science, 89(7),1259-1262.

Mathur, S.C., Gaur, S.D., Loyal, R.S., Tripathi, A. \& Sisodia, M.S.(2005b). Spherules in the Fatehgarh Formation (Cretaceous) of Barmer Basin, India. Gondwana Research, 8(4),579-584.

Mathur, S.C., Mathur S.K. \& Loyal, R.S. (2006). First Report of micro-vertebrate assemblage from Cretaceous Fatehgarh Formation. Geological Society of India, 67(6), 759-769.

Mathur, S.C., Loyal, R.S., Nama, S.L. \& Negi, N.S. (2009). Geological Constraints on the Bentonitic facies of the Barmer Basin, Western Rajasthan, India. In: Economic Mineralization, K.L. Srivastava (eds.), Scientific Publisher (India), 274-286.

Mathur, Saurabh., Shekhawat, N.S. \& Parihar, V.S. (2016). First discovery of Asthenopodichnium Lithuanicum trace fossils from the Barmer Hill Formation, Western Rajasthan, India. Geoyouth-2016, M.L.S University, Udaipur, 8-9 (extended Abstract).

Mathur, S. C., Shekhawat, N. S., Nama, S. L., Khichi, C. P., Soni, A., Mathur Saurabh \& Parihar, V. S. (2018). The wood-boring trace fossil Asthenopodichnium from Palaeocene sediments of the Barmer Hill Formation, western Rajasthan, India. Current Science, 114(1544), 1544-1548.

Mathur, S., Tripathi, R.P., Mathur, S.C., Mathur, Mathur Saurabh. \& Gaur, S.D. (2019). Implication from chemical study of Magnetic spherules from a thin ferruginous layer located in Fatehgarh formation of Barmer Basin, India. Jour. Geol. Soc. India,93,56-60.

Mehrotra, R.C.,Mandaokar, B.D.,Tiwari, R.P. \& Rai, V. (2001). Teredolites clavatus from the Upper Bhuban Formation of Aizawl District Mizoram, India.Ichnos,8,63-68.

Moran, K., Hilbert, H. L., Golder, K., Malenda, H. F., Smith, C. J., Storm, L. D., Simpson, E. L., Wizevich, M. C. \& Tindall, S. E. (2010). Attributes of the wood-boring trace fossil Asthenopodichnium in the Late Cretaceous Wahweap Formation, Utah, USA: Palaeogeography, Palaeoclimatology, Palaeoecology, 297,662-669.

Paul, F., Bodapati, S., Naidu, N., Burley, S.D., Dolson, J., Whiteley \& Kothari, N.V. (2015). Geochemical characterization of oils and their source rock in the Barmer Basin, Rajasthan, India. Journal Petroleum Geosciences, 21, 321.

Roy, A.B. \& Jakhar, S. (2002). Geology of Rajasthan (North West India) Precambrian to Recent. Scientific Publishers, (India), Jodhpur,421.

Santucci, V. L. (2017). Preserving Fossils in the National Parks: A History. Jour. Earth Science History, 36 (2),245-285.

Shekhawat, N.S. (2016). Geological Investigation of rocks of Barmer Hill Formation of the petroliferous Barmer Basin, Western Rajasthan, India.(Unpublished thesis), J.N.V.University, Jodhpur, 187.

Srivastava, R. K. (1988). Alkaline and peralkaline rocks of RajasthanMem., Geol. Soc. Ind.15,24-32.

Tiwari, R.P., Malsawma, J., Sangode, S.J., \& Arora, B.R. (2007). Magnetostratigraphy of a part of Middle Bhuban sequence (Surma Group) Aizawl, Mizoram. Journal of the Geological Society of India, 70,667-674.

Uchman, A. (1995). Taxonomy and palaeoecology of flysch trace fossils: Marnosoarenacea Formation and associated facies (Miocene, Northern Apennines, Italy).Beringeria, 15,3-11.

Uchman, A., Gaigalas, A., Melešytè, M. \& Kazakayskas, V. (2007). The trace fossil Astheropodichniumlithuanicumisp. Nov., from the late Neogene brown-coal deposits, Lithuania. Geological Quarterly, 51, 329-336.

Yang, G., Chen,Z., Tian, M., Wray, R. A. L. \& Ping, Y. (2011). On the growth of national Geoparks in China: distribution, interpretation and regional comparison. Episodes, 34 (3), 157-176.

*** GGN, (2006). Guideline and criteria for national Geopark Seeking UNESCO'S assistance to join the Global Geopark Network. UNESCO, Division of Ecological and Earth Science,115-118.

*** GGN Website: http://www.globalgeopark.org/ globalgeoparksnetwork.org

** GSI, (2001a). Monument of stratigraphic significance:Malanivolcanics overlain by Jodhpur Sandstone, Memo. Geological Survey of India,27,62-64.

*** GSI. (2001b). National Geological Monuments, Jodhpur. Group- Malani Igneous Suite contact Memo. Geological Survey of India,27,64-65.

*** UNEP-WCMC. (2011). Wadi Al-Hitan (Whale Valley), Egypt, UNEP-WCMC World Heritage Information Sheets. [Electronic reference]

Submitted:

09.10.2019
Revised:

17.02.2020
Accepted and published online 25.02.2020 